\title{
Pinch Strength
}

National Cancer Institute

\section{Source}

National Cancer Institute. Pinch Strength. NCI Thesaurus. Code C139211.

An assessment of hand muscle strength that measures that force with which one squeezes or compresses an object using one's thumb and one or multiple fingers. 